\title{
TCOM \\ An examination of Tunisian fact-checking resources in the context of COVID-19
}

\section{Fredj Zamit, Arwa Kooli and Ikram Toumi}

\begin{abstract}
The study examines the effect of COVID-19 on the fact-checking resources in Tunisia. Through developing monographies, we traced the trajectory of most fact-checking platforms in the Tunisian media and explored their teams and working strategies. We noticed a clear spike in the creation of fact-checking platforms during and after February 2020 and determined that the pandemic created a context in which these platforms emerged and flourished. However, many of these platforms, were a product of journalists' individual initiatives and lacked a clear editorial and strategic inclusion of fact-checking. Besides, we found a lack of prior training and an absence of fact-checkers specialized in science and health communication.
\end{abstract}

Keywords

Science and media; Misinformation; COVID-19; Fact-checking; Professionalism, professional development and training in science communication

DOI

https://doi.org/10.22323/2.19070204

Submitted: 30th June 2020

Accepted: 21st September 2020

Published: 14th December 2020

Introduction

On February 15, the Director-General of the World Health Organization (WHO), Tedros Adhanom Ghebreyesus, addressed the Munich Security Conference saying:

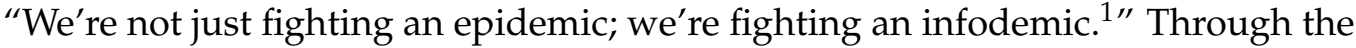
use of the term infodemic, Tedros was emphasizing the overflow of information surrounding the spread of COVID-19, the illness caused by the novel coronavirus. Health specialists, politicians, media personalities, and citizens all over the world have been part of the infodemic by disseminating information about the virus. This has contributed to the already existing overwhelming amount of information that marks today's society often referred to as "information overload" [Lee, Son and Kim, 2016; Pulido et al., 2020]. More and more, managing the wealth of information surrounding us requires a skillful understanding and usage of the media not only because of its abundance but also because this information is often false, lacking accuracy and scientific basis. \footnotetext{
2020).

${ }^{1}$ https://www.who.int/dg/speeches/detail/munich-security-conference (accessed on 15 May 
Misinformation about the coronavirus ranges from fake news to hoaxes and myths. We have seen misinformation about the virus source with claims that it came from bat soup or from a Chinese or American lab, as well as a broad range of DIY preventive remedies including oregano, garlic, and salty water, to name a few [Pulido et al., 2020]. News from health practitioners were not always accurate either given the lack of knowledge about the virus [Orso et al., 2020]. In his February speech, Tedros pointed to the risk paused by misinformation stating that "fake news spreads faster and more easily than this virus, and is just as dangerous." Indeed, in the context of a pandemic, false news is not just confusing, it directly affects public health. It negatively affects how individuals construe the situation and hinder public health officials' interventions and efforts to fight and contain the spread of the virus [Cinelli et al., 2020; Pulido et al., 2020].

Consequently, the pandemic has also led to a surge in the number of fact-checking resources and platforms around the world. The WHO organization dedicated a website to fact-checking titled: "Myth Busters. ${ }^{2 "}$ The WHO also supports and funds world campaigns to fight false news such as the "Stop The Spread" global campaign. Many governments and media organizations around the world have also invested in fact-checking, either by creating new platforms dedicated to investigating COVID-19 information, or by supporting existing platforms.

The present article focuses on the Tunisian fact-checking resources. In 2011, Tunisia, a North African country with an 11.5 million population, went through an uprising that overthrew its authoritarian regime of more than 50 years. The revolution liberated its media and generated newfound freedom of speech and media participation making Tunisia an interesting case of study for exploring media environment during the pandemic. Tunisia's management of the pandemic was relatively successful. As soon as the first cases appeared in mid-March, the country closed its borders and issued stay-at home orders, which resulted in low numbers of cases (3969), death (80), and recoveries (1624) as of August 31 (2020). The Tunisian health officials held daily news conferences to update the public about the outbreak. They often warned against the spread of false information, especially ones downplaying the virus or suggesting home remedies to avoid contracting the virus. In March, a rumor spread in Tunisian social media indicating that garlic prevents and cures coronavirus infections. Thus, Tunisians rushed to buy garlic leading to a sharp rise in its prices [Alaoui, 2020]. This misinformation and many others demonstrated the critical role of fact-checking in today's media environment. It led to a raise in the number of Tunisian fact-checking activity and platforms.

The key objective of this study is to examine the impact of COVID-19 on fact-checking in Tunisia as we identify its resources and practices. We attempted to respond to the following question: How did the COVID-19 pandemic affect the state of fact-checking resources in Tunisia? The paper is divided into 2 main parts. First, we review how misinformation and fact-checking have been defined by scholars especially in the context of the Coronavirus infodemic. Second, we compile an inventory of fact-checking resources in Tunisia, trace their life cycle (inception and growth), discuss the type of media in which they operate (broadcast, written, and electronic), and examine their fact-checking teams and strategies. In

\footnotetext{
${ }^{2}$ https:/ / www.who.int/emergencies/diseases / novel-coronavirus-2019/advice-for-public/mythbusters (accessed on 15 May 2020).

${ }^{3}$ https: / / www.cdc.gov / coronavirus / 2019-ncov/daily-life-coping/share-facts.html (accessed on 15 May 2020).
} 
addition to adding to the literature about the Tunisian media ecology during the pandemic, this paper attempts to provide a review for future scholars and practitioners who wish to understand the current state of fact-checking in Tunisia and the impact of COVID-19 on its media landscape.

The Tunisian media scene has historically given insufficient attention to fact-checking, despite the fact that, like all other countries, Tunisia's media environment is infected by misinformation. In 2011, as a consequence of political change, Tunisia passed a decree-law making it illegal to spread misinformation. Tunisians who deliberately fabricate news to mislead the public or create havoc must pay a fine and can be sentenced to prison in extreme cases [Alaoui, 2020]. However, that did not slow the spread of false information in the Tunisian media platforms. "Fake news" is the most frequently used term to refer to false information circulating in the media. Nevertheless, media and communication scholars focusing on COVID-19 are avoiding the use of the term "fake news" because of its political connotation and its inability to account for the range of false information about the pandemic [Cinelli et al., 2020]. Furthermore, fake news has been used in the literature to describe news intentionally fabricated with the purpose of influencing and maintaining control of citizens' behavior and opinion [Waisbord, 2018; Carr, Sanchez and Daros, 2020]. The same applies to the term "disinformation," which has been used to refer to information that was communicated as true when the communicator is aware of its fallacy [Krause et al., 2020]. However, false information about COVID-19 includes hoaxes, myths, and information from health officials which did not intend to mislead the public but were not necessarily accurate [Orso et al., 2020]. Thus, many scholars opted for the use of the term "misinformation" in their discussion of the spread of false information about COVID-19 [Carr, Sanchez and Daros, 2020; Casero-Ripollés, 2020; Cinelli et al., 2020; Krause et al., 2020]. Krause et al. [2020] defined misinformation as "any messages that conflict with the best-available evidence about COVID-19 and would likely not be correct if they were challenged." As this definition fits the purpose and the context of this paper, we decided to adopt this line of literature and use the word misinformation in our discussion.

The accessibility of social media has intensified the spread of misinformation by providing platforms and tools for everybody regardless of their digital and media literacy to create and circulate news and information making the verification of news more complicated [Hassan et al., 2015]. User generated content (UGC) represents a considerable proportion of online publications. Figueira and Oliveira [2017] argue that news publishers have lost control over news distribution. Besides, social media create a familiarity with content creators and a sense of credibility that leads consumers to trust the content these influencers produce or share [Cinelli et al., 2020; Orso et al., 2020]. Orso et al. [2020], add that people in general and social media users in particular, tend to trust and share information that fit into their personal beliefs regardless of its degree of accuracy. Thus, social media have become a platform where misinformation about the outbreak multiply and thrive. The spread of misinformation leads to a variety of responses that can be detrimental to the government's efforts to contain the outbreak, which is why health officials are attempting to manage public information in addition to managing the virus itself [Cinelli et al., 2020]. That is why, while it is always a 
necessary part of the information dissemination process, fact-checking is extremely critical in the context of a pandemic.

Fact-checking is defined as the process of assessing the accuracy of claims found in the mass media or made by public figures and citizens alike [Vlachos and Riedel, 2014]. In the context of COVID-19, it has been defined as the conscious attempt to verify myths and information about the outbreak [Krause et al., 2020].

Fact-checking has increased as the virus spread [Krause et al., 2020]. Brennen et al. [2020] reported that English language fact-checking has intensified by more than $900 \%$ since January 2020. Many fact-checking platforms were launched specifically to evaluate information about the pandemic [Krause et al., 2020]. However, most well-established journalism entities have a fact-checking mechanism in place [Krause et al., 2020]. Besides, journalists are trained to verify and ensure the credibility and accuracy of the information they receive and send to their audience [Vlachos and Riedel, 2014]. That is why, COVID-19 led the audiences to reconnect with traditional media as people turn to broadcast news and media they judge as more credible and professional in times of a crisis [Casero-Ripollés, 2020].

Thereby, it is critical to examine not only the platforms but also the environment and the contextual time and space if we aim to have a comprehensive understanding of the way they function. Fact-checking is often conducted manually by journalists who are trained in the subject [Vlachos and Riedel, 2014]. That is why some scholars [Goasdoué et al., 2013] use the phrase "fact-checking and analysis" to indicate the complexity of the process and evaluation part of it. It is also the reason why many scholars argue against automated fact-checking, which refers to the use of an automatic process or software to investigate information by comparing it to digitized datasets, surveys, and reports [Vlachos and Riedel, 2014]. However, fact-checkers who use automated fact-checking must detail their process as scholars argue that transparency is necessary for artificial intelligence fact-checking systems in order for users to trust it [Nguyen et al., 2018]. Furthermore, scholars maintain that information can be multilayered and requires a complex evaluation of the context, the source, and the audience, a matter that is not possible with an automated procedure [Krause et al., 2020; Vlachos and Riedel, 2014]. That being said, the alternative strategy, manual fact-checking, can also be problematic as it is not free of bias [Krause et al., 2020; Graves, 2017]. It requires a significant amount of individual evaluation of the news and the truth value assigned to the information does not always end with a clear false or true verdict and can sometimes be assigned a "somewhat true" or "somewhat false" [Vlachos and Riedel, 2014]. It is one of the reasons why fact checkers often detail their analysis process and must justify the verdict assigned to the information [Vlachos and Riedel, 2014].

Many scholars suggest that a combination of both methods, human and automated processes, will lead to a better fact-checking outcome [Goasdoué et al., 2013; Vlachos and Riedel, 2014]. Furthermore, while some scholars assign more value to traditional media institutions, others recognize that fact-checking connects different media platforms, traditional and new [Vlachos and Riedel, 2014]. The idea is that there is a constant transfer of news and fact checked information between TV and radio shows, news websites, and social media pages. Hence, it is more productive to explore how different platforms and processes operate in relation to each other rather than in isolation or competition with each other [Chadwick, 2017; Krause et al., 2020]. 
This study aims to examine the impact of COVID-19 on fact-checking in Tunisia as we identify and map its resources and platforms. To achieve this aim, we compiled a list of fact-checking resources and initiatives in Tunisia. Second, we built an inventory of fact-checking resources in Tunisia by collecting data about the 3 following research features: (1) the platforms' life cycle (inception and growth), (2) the type of media in which they operate (broadcast, written, and electronic), and (3) the fact-checking teams and strategies. In this section, we detail the data collection and analysis process and describe the Tunisian media environment in order to facilitate the understanding of our results.

Tunisia's media profile. Broadcast media remains the most popular media outlet in Tunisia with two public broadcast media establishments, "Tunisian National Radio," which runs 9 radio channels, and "Tunisian National Television," which runs two national TV channels. In addition, there are 9 private TV stations, 17 commercial radios and 22 associative radios. ${ }^{4}$ Given its relatively small size and population (11.5million, 2020 est.), Tunisia has one national press agency, "Tunis Africa Press" (TAP), one public journalism and communication school, "The Institute of Press and Information Sciences" (IPSI), and one public training center, "The African Center for the Development of Journalists and Communicators" (CAPJC). In addition to the public platforms, several independent and NGO media and journalism entities operate and enrich the Tunisian media ecology, mainly after the 2011 political change which has ended the dictatorial regime. On the electronic side, Tunisia is one of the leading countries in Africa in terms of ICT with high internet penetration rates and computer and mobile ownership (Tunisian Institute of Statistics ${ }^{5}$ ). While around 50 periodicals continue to operate in the country, newspaper sales continue to decline as their readers make the transition online. Indeed, social media news pages and organizations have become a popular source of news information for Tunisian audiences. Facebook is the most popular social media platform with about 7.5 million subscribers. ${ }^{6}$ The 2011 revolution has resulted in a newfound freedom of press and speech. However, in the current democratic transition context, the Tunisian media landscape could be described as vulnerable and volatile.

Procedure. To map fact-checking resources in Tunisia, we traced media initiatives related to fact-checking. We searched well-known and established organizations (with a focus on the ones operating legally) as well as new initiatives emerging in electronic pages, TV, and radio shows. We followed announcements about fact-checking training, new platform initiation, debriefings, and compiled a list of electronic platforms used by media and public figures. We joined Facebook groups in order to observe the material they share and the way they are working. Eventually, we obtained a list of 15 fact-checking resources as shown in Table 1 below. Indeed, given the context of the pandemic, as we are finalizing this paper, many new initiatives are currently in development.

\footnotetext{
${ }^{4}$ We list here media institutions existing legally and published on the Arabic version website of the broadcasting regulation body: https:/ / bit.ly/387V7Oc (accessed on 27 August 2020).

${ }^{5} 2018$ Annual Report, The National Institute of Statistics, Tunisia: https://bit.ly/31pNe59 (accessed on 6 June 2020).

${ }^{6}$ Internet World Stats: https:/ / www.internetworldstats.com/stats1.htm (accessed on 28 June 2020).
} 
To obtain monographies about the fact-checking corpus, we developed a list of questions covering every aspect of the proposed research question then used two main approaches to answer them: First, we searched the platforms to acquire information about it and collected documents from fact-checking training centers, trainers, and relevant administrative staff. Second, given our inability to answer all our questions through the first approach, we opted for directly contacting the fact-checking resources' personnel of each platform to interview them and collect data about the lacking information. We contacted them mainly via phone calls but also using mail and social media direct messaging. The interviews were conducted by the authors of this paper and were rather informal. We changed the 3 features/statements above into questions and posed the same questions on all the interviewees.

We ended up contacting all platforms and interviewing 14 editors in chief and fact-checking staff from May 15 through June 15 and were unable to get in touch with one of the resources. ${ }^{7}$ We contacted the editors/journalists/owners/administrators of 4 radio platforms, 1 television platform, 7 websites, and 3 social media groups and pages.

Table 1. A distribution of the number of fact-checking platforms based on the type of media.

\begin{tabular}{|l|r|}
\hline \multicolumn{2}{|l|}{ Traditional media } \\
\hline Newspapers & 0 \\
\hline Radio & 4 \\
\hline Television & 1 \\
\hline New media \\
\hline Websites & 7 \\
\hline Social media & 8 \\
\hline Total & 3 \\
\hline
\end{tabular}

The aim was to map the resources and collect information about the following features: (1) the Institutions and type of media in which they operate; (2) timing and reason of the inception; (3) the fact-checking teams, procedure, strategies, and dissemination channels.

Analysis. We used the 3 features discussed in the previous section to organize and categorize the data collected. We created tables (Index 1, appendix A) to distribute the answers into categories based on the type of media (traditional vs. new) and the feature categories. We created new categories for the data collected during the interview that appeared as the interviewees were speaking. For example, we did not inquire about the platforms' view of each others' (other platform) work, which was a recurrent theme in the interviewees' responses. Thus, we created a category for that type of information. At the end, our analysis table contained 7 categories (as shown in Index 1, appendix A and 2, appendix B), which we used as analysis themes. In the results/discussion section, we describe the data collected, discuss how the results fit in the existing literature, and offer our personal insight on the findings.

\footnotetext{
${ }^{7}$ The team of the platform Berrasmi.tn is unreachable.

${ }^{8}$ The number refers to platforms existing solely on social media as Facebook groups or pages. It does not include other resources which have Facebook pages to support their main platforms.
} 
Tunisian TV and radios are the cradle of early fact-checking projects. From fall 2017 to Spring 2018, a Tunisian TV political discussion show, 75 Minutes, included a fact-checking segment. In 2018, the public radio station, Tunis International Radio Channel (RTCI), launched a 15 minutes segment titled "On a Vérifié Pour Vous" [We Have Verified For You] in its daily French program "Good Morning Tunisia." The segment was proposed and created by a journalist who attended a skills workshop about explanatory journalism in which fact-checking was mentioned. Similarly, the fact-checking segment الصّحيح مالغالط "Esshih Mel Ghalet" [The Truth of the False] of the private local radio station "Diwan FM" was created by a journalist after she attended a fact-checking training. In fact, none of the outlets, especially traditional media ones, added fact-checking based on a strategic, editorial planning, which explains why most of these early experiences did not last, as shown in Index 3, appendix C. For example, "On a Vérifié Pour Vous" was discontinued in 2019 when the journalist who initiated it could not run it anymore. It also explains why fact-checking services existed solely in the form of segments within shows instead of independent programs or online platforms. Prior to the pandemic and with a lack of strategic planning, attending a fact-checking training was one of the main instigators of fact-checking platforms, which demonstrates that trainings and workshops are indispensable to improve journalism practices and the quality of the content audiences receive.

On the other hand, election campaigns appear to be a critical factor in the genesis of fact-checking resources in the pre-COVID-19 era. The first platform was launched in 2014 during the first free Presidential elections campaign. Birrasmi $i^{9}$ [For Real], an online Fact-checking platform, was founded by the Tunisian NGO "Les Cahiers de la Liberté" to verify politicians' claims. Although a pioneer in fact-checking, as a specific online device, Birrasmi is different from ordinary fact-checking platforms whose work is not limited to election time. This type of fact-checking platforms is quite common. Its operation is limited to election campaigns and goes dormant in between elections. In the U.S., for example, Politifact ${ }^{10}$ is dedicated to political statements and is particularly active during elections. Similarly to Politifact's Truth-O-Meter, Birrasmi stamps political claims with a "True", "False", "mostly false" or "mostly true" ratings.

The political transition context in Tunisia is playing an essential role in the emergence of fact-checking platforms as it was difficult for the media to function effectively in the pre-2011 authoritarian regime. After the political change of 2011, the Tunisian press carried on introducing innovative practices and redesigning its basic functioning principles. It is reclaiming its social responsibility by weeding out misinformation affecting the peaceful and democratic transition. Zhou and Zafarani [2020] argue that "Fake news is now viewed as one of the greatest threats to democracy, journalism, and freedom of expression" (p. 1). Consequently, fact-checking is considered a necessary practice to support the fragile political transition through filtering out misinformation. It is also a means to rebuild trust in the media when they function in a context shaped by a general sense of mistrust [Bigot, 2017], in which past authoritarian regimes and social media play a big role.

\footnotetext{
${ }^{9}$ http:/ / birrasmi.tn/ (accessed on 28 August 2020).

${ }^{10}$ https:/ / www.politifact.com/ (accessed on 15 June 2020).
} 


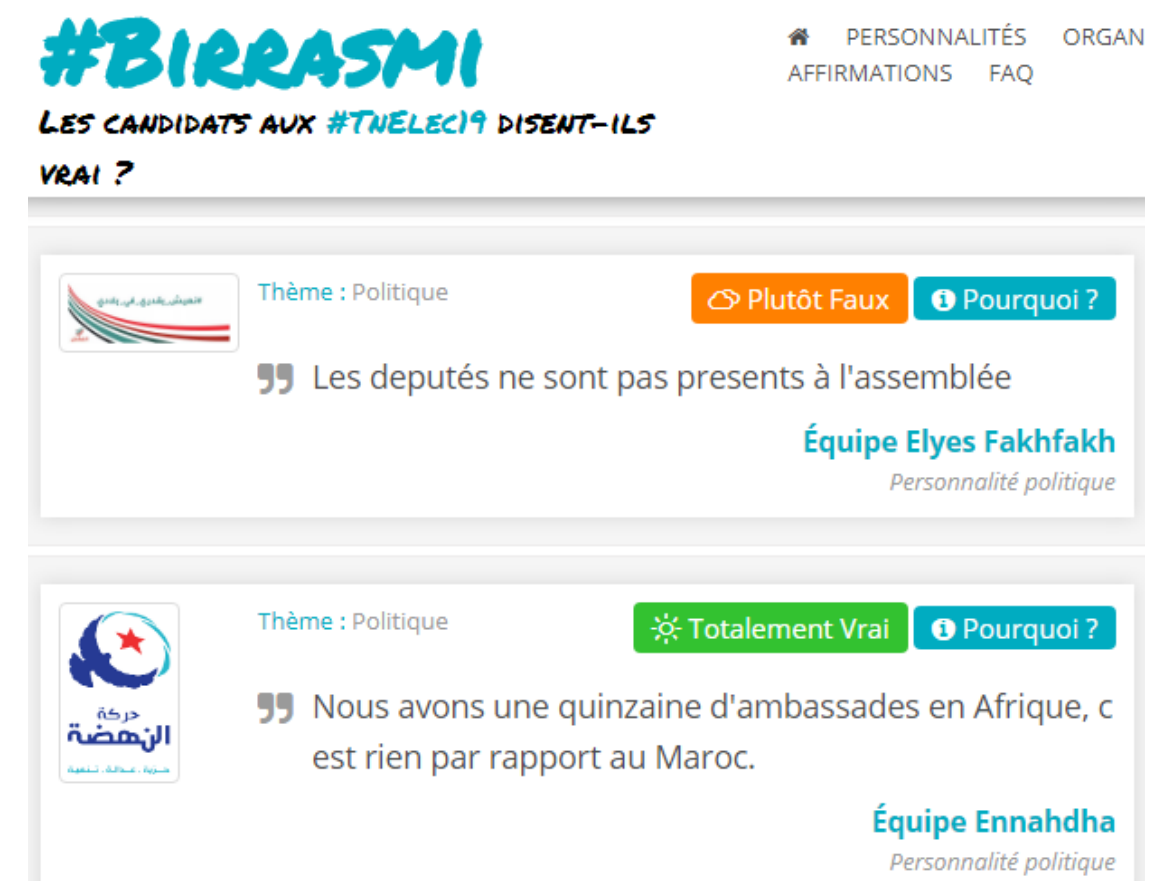

Figure 1. A screenshot from Birrasmi's website. It demonstrates an example of statements assigned to the news. The statement on top, in orange, is a "mostly false" while the one below in green is "totally true" verdict.

Recent researches about the public perception of fact-checking show a significant segment of social media users remain skeptic toward this technique [Brandtzaeg, Følstad and Chaparro Domínguez, 2017; Nguyen et al., 2018]. In general, transparency remains crucial and necessary for artificial intelligence fact-checking systems in order to help users trust it [Brandtzaeg, Følstad and Chaparro Domínguez, 2017; Nguyen et al., 2018]. In the Tunisian context, there is no vigorous research about fact-checking audience perception. But a lack of transparency is a main characteristic of the media environment in the post revolution era [Chouikha, 2015]. That being said, it is important to note that fact-checking should not be considered the ultimate antidote to fake news and public mistrust. Many other internal and external factors intersect - e.g. building a sense of trust in the institution itself, the journalists and reclaiming their social responsibility, and their funding sources- must be considered. The solution to the sense of mistrust in the Tunisian media should be viewed as a process rather than an immediate remedy.

Tunisia Check News, was one of the platforms initiated specifically to help citizens develop informed opinion about candidates during election campaigns. The platform was initiated in September 2019 by the High Independent Broadcasting Regulation Authority (HAICA) ${ }^{11}$ and involved multiple media institutions such The Tunisian National Television, National Press Agency TAP, and National Public Radio. The Tunisian National Television launched its own online fact-checking

\footnotetext{
${ }^{11}$ The High Independent Broadcasting Regulation Authority is a constitutional commission created in 2013 to ensure that the Tunisian media's practices are ethical and legal. Its existence demonstrates the fragile democratic transition as it was created by a decree-law in the aftermath of the 2011 uprising and should have been replaced by a new fundamental law by 2019 , which has not happened yet. It has the task to survey the audiovisual broadcasting and to attach specific laws in this field. It also oversees ethical role.
} 
platform in 2019 but a few months after its inception, the website ${ }^{12}$ is no longer available. Journalists attached to these establishments, fact-check news and publish their verdicts on the platform. Given the large number of partisan information about opposing candidates, the platform was mostly active during legislative and presidential elections in 2019. According to the platform's mission statement, the aim is to counter misleading information, reestablish journalism ethics, and protect the democratic transition of the post 2011 revolution. Similar to the other election campaign focused platforms, Tunisia Check News went into a sleep mode following the 2019 election. That is until the COVID-19 virus outbreak.

\section{COVID-19, civil society and fact-checking}

A combination of COVID-19 and the Tunisian civil society created a successful formula for the emergence of numerous fact-checking initiatives in Tunisia in both the traditional and the new media. Birrasmi was created by "Les Cahiers de la Liberté", an NGO founded by Tunisians residing in France and abroad while Tunisia Check News was funded by local and international organizations such as the EU and the Geneva Center for Governance in the Security Field. Birrasmi was the first and only fact-checking platform created in 2014 by the NGO Les Cahiers de la Liberté. As shown in the Graph, the next platforms appear in 2017. During 2018, 3 fact-checking sections were created in Radio programs. However, 2020 saw a sharp increase in the number of the resources and platforms due precisely to the COVID-19 outbreak. Figure 2 below demonstrates the peak in the number of platforms during the pandemic.

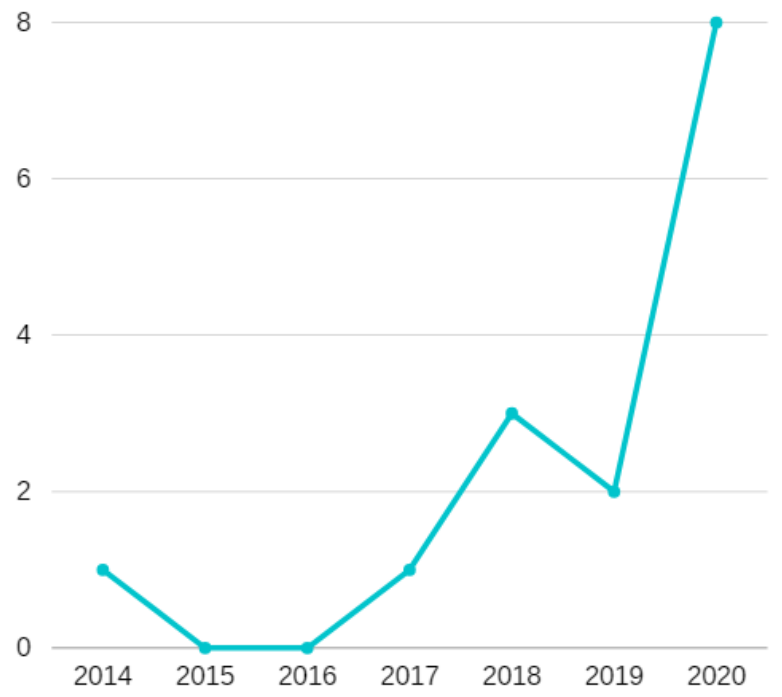

Figure 2. A graph showing the evolution of fact-checking platforms inception between 2014 and 2020. Their number grows considerably during the pandemic.

Between February and April 2020 many new social media fact-checking platforms were created, especially on Facebook, targeting the pandemic wave of misinformation. The Facebook page Falso [Fake] was created a few weeks after the general confinement in Tunisia and the website was launched about a month

\footnotetext{
${ }^{12}$ factchecking.watania1.tn.
} 
later. ${ }^{13}$ The same goes for El Khabar Moukades ${ }^{14}$ [News is Sacred], which Facebook group page shows the slogan "In order to avoid making the truth a victim of COVID-19." However, its page is not as active as Falso or Tunisia Check News.

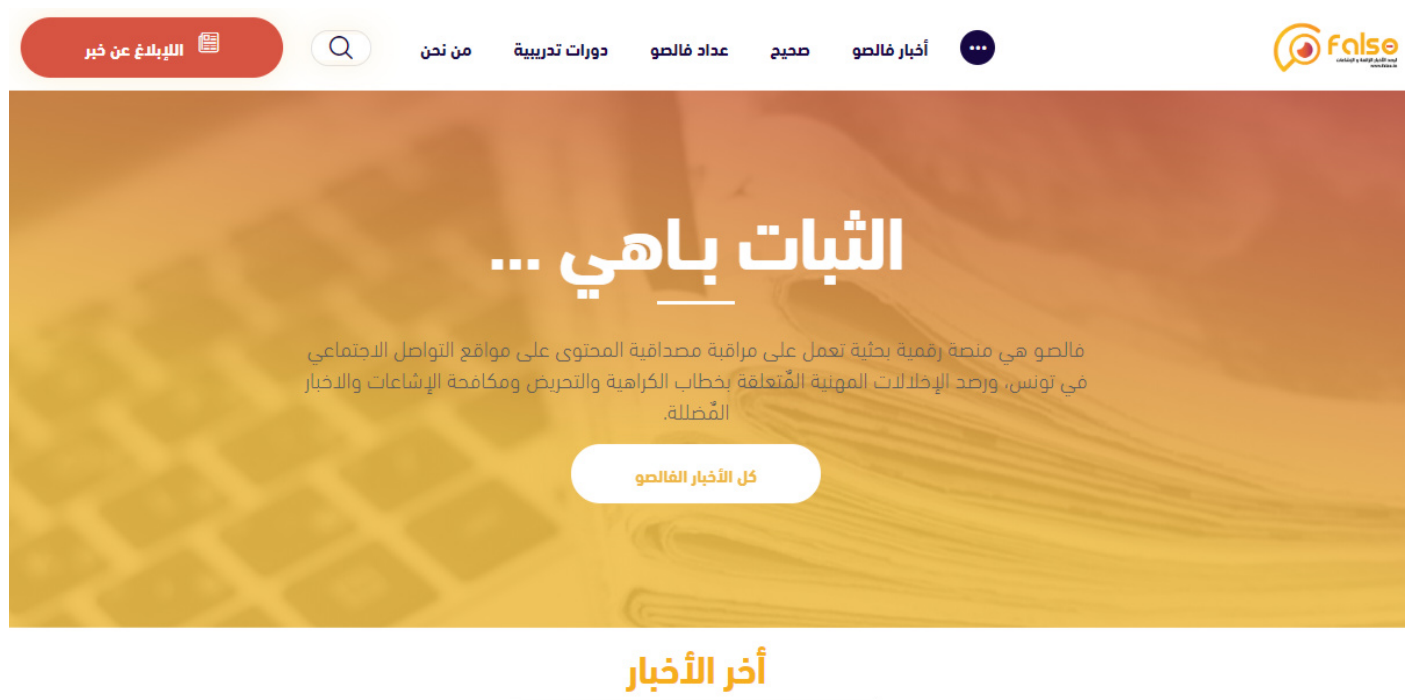

Figure 3. Falso's website showing its Arabic language slogan, "it's good to be accurate."

Other platforms were planned before the outbreak but were carried out between February and April of 2020. For example, the Tunisian NGO, IWatch, launched its fact-checking online platform, Icheck.tn, in April 2020. The idea was developed during the 2019 elections following a rise of sponsored content and of Facebook pages using misinformation to attack some candidates and support others. However, the NGO was unable to realize its platform in 2019 due to the lack of funding. Following the COVID-19 outbreak, the idea was revived and received a grant from the Carter Center to support IWatch's efforts to combat the spread of pandemic-related misleading news. Similarly, the Facebook page, Falso, and a Facebook group, El Marsad Ettounsi Li Moukafahet El Akhbar Ezzaifa ${ }^{15}$

[The Tunisian Observatory for the Fight against Fake News], were designed prior to the COVID-19 outbreak but only saw the light during the pandemic. Currently, Falso and Icheck can be classified as the most important fact-checking initiatives given their audience and the number of news they verify on a daily basis. Falso, which was launched by a group of Tunisian activists, has more than 14,000 fans on its Facebook page, the largest number of followers of all fact-checking pages and groups. When interviewed for this report, some of the founders of these groups and pages asserted that their platforms will remain active post COVID-19 as they suspect that misinformation will decline but not completely disappear (Falso and Icheck), while others asserted that it is a COVID-19 related project and will discontinue by the end of the pandemic ( $E l$ Khabar Moukades). Others, such as Nawaat, stressed that although their platforms were created to adapt to the COVID-19 context, they are in a trial period and will

\footnotetext{
${ }^{13}$ URL: https: / / falso.tn / (accessed on 27 June 2020).

${ }^{14}$ The name of this Facebook group is inspired from the journalistic principle "Fact is sacred". The group includes professional journalists and researchers in Information and Communication Science. The founder of this group is a professional news reporter and journalism professor.

${ }^{15}$ The private Facebook group includes professional and citizen journalists.
} 
decide the future of their platform based on their performance during the pandemic. The independent collective community and blog, Nawaat, launched in

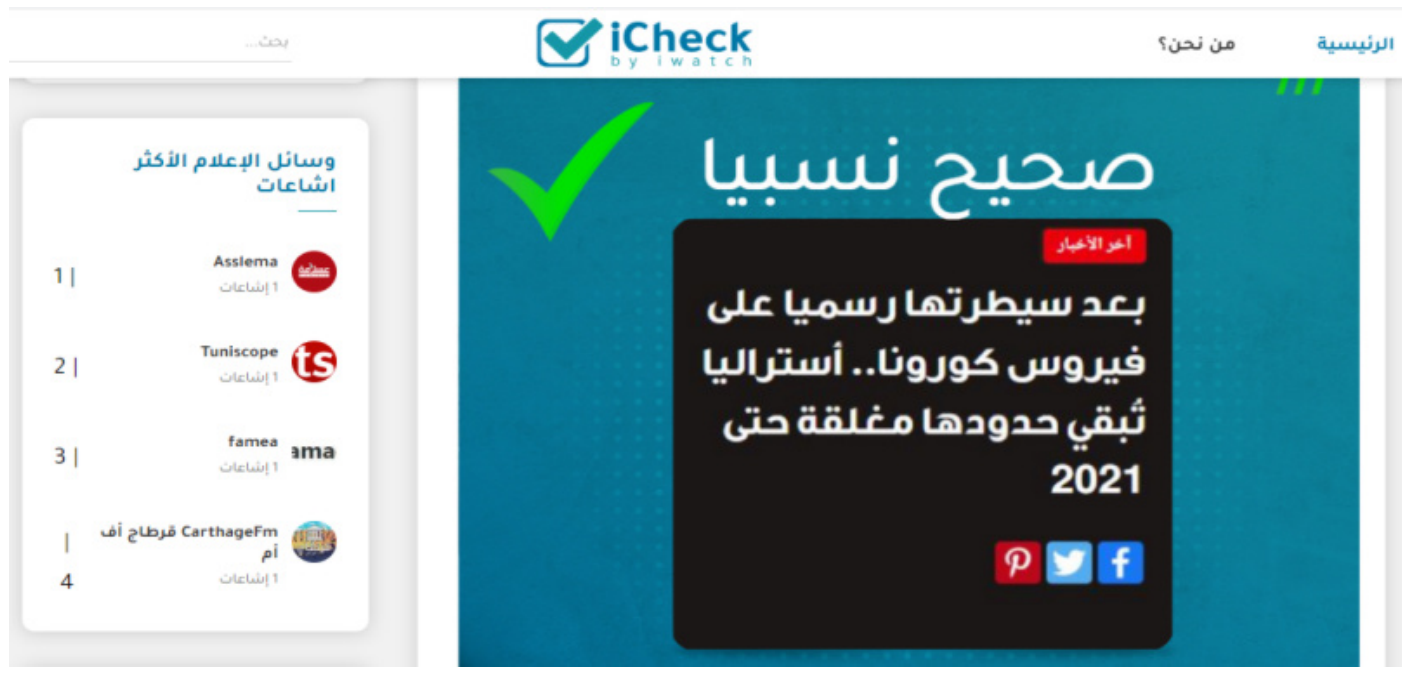

Figure 4. A screenshot of the fact-checking platform, ICheck, initiated by the NGO I Watch. The screenshot shows a green check as a "somewhat true" verdict on a COVID-19 information.

March 2020 its own fact-checking segment. It is called Nawaat Fact Check. ${ }^{16}$ It offers articles in Arabic, French, and English. Nawaat.org became an associative media platform after 2011. Kashf Media is a new NGO media platform created in 2020 and focuses on topics related to the northwestern part of Tunisia. From its conception, Kashf Media considered creating a segment called Kashf Khabar [Reveal News] as a fact-checking service.

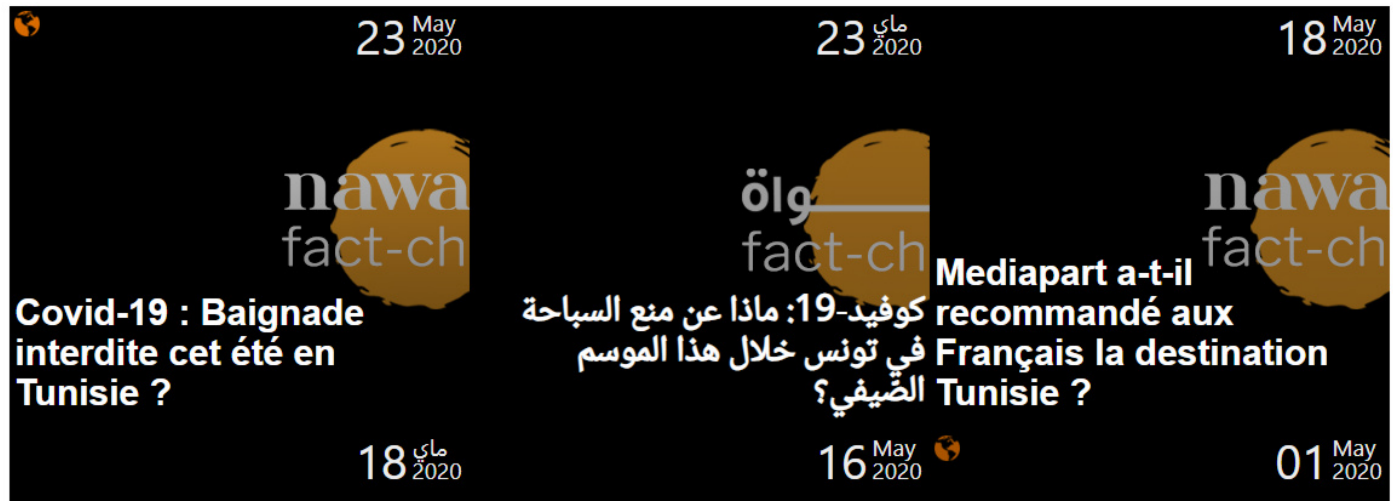

Figure 5. A screenshot of Nawaat's fact-checking platform, "Nawaat Fact-check".

On a different note, several platforms were initiated by private and public institutions. The private radio station, Shems FM, launched a program called Corona News, which included a fact-checking segment about the COVID-19 infodemic titled Haw Eshih [Here is the Truth]. In 2019, the private online

\footnotetext{
${ }^{16}$ URL: http: / / nawaat.org/portail/tag/nawaat-fact-check/ (accessed on 27 June 2020).
} 
newsmagazine, Business News, started a special section dedicated to fact-checking. The section titled BN Check was the most active during the 2019 elections then again during the COVID-19 outbreak. Out of the 8 new platforms created before
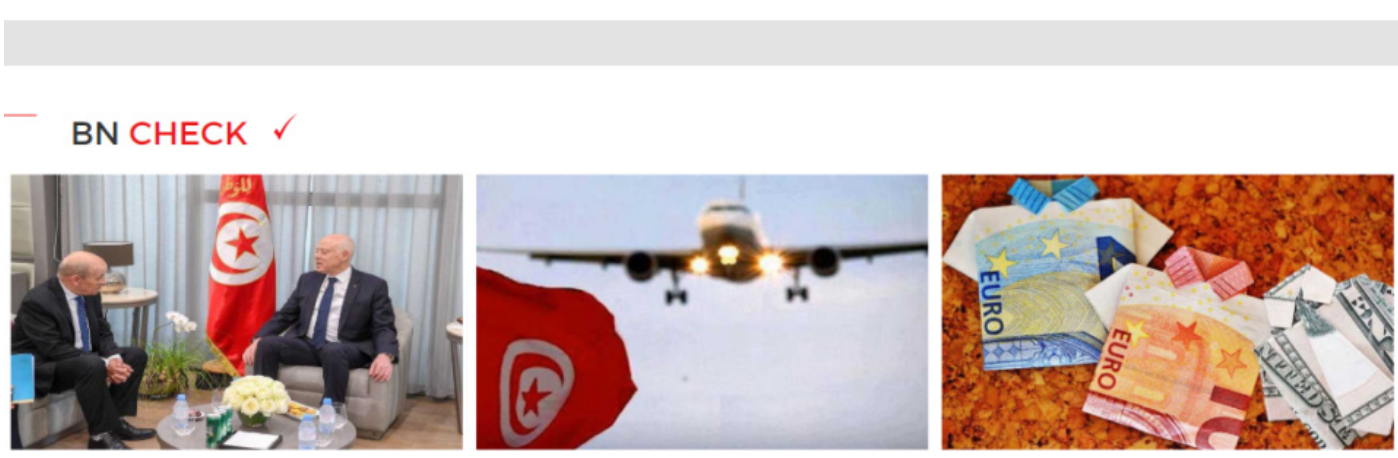

Figure 6. Business News fact-checking platform, BN Check.

and at the beginning of the pandemic, more than half was created by NGOs. The 2011 political change has offered the freedom of operation and speech to NGO which enhanced their number and their role in the Tunisian media and political landscape. Besides, the majority of fact-checking platforms created during the pandemic are Facebook pages and groups. They are individual initiatives stemming mostly from persons active in the media field. Although a double-edged sword (both a vehicle of misinformation and a tool to counter it), social media gave a channel through which journalists and media establishments can react rapidly and efficiently to the infodemic.

In addition to instigating the creation of new platforms, COVID-19 stimulated stakeholders to resuscitate old projects. The online platform Tunisia Check News was created in September 2019 especially for the elections, as it is specialized in political fact-checking, and was discontinued right after. However, the pandemic encouraged journalists to relaunch this platform. The dormant platform went active mid-March and has since checked and published More than 40 news about COVID-19. Similar to other platforms mentioned earlier in the discussion, the resuscitation of this platform was an individual initiative of the journalists working at the Tunisian national TV using the same election design and strategy.

Furthermore, its staff was unable to confirm whether it will remain active after the pandemic, which further demonstrates the fragility and lack of strategic planning of these projects.

The online news magazine Nawaat created Nawaat fact check as a fact checking service mainly motivated by COVID-19 misinformation, even though they have been engaged in fact-checking as a collaboration with the French Newspaper, Libération, since 2018. The introduction of IWatch fact-checking project was also accelerated by the pandemic. Falso's main motivation to create the platform was the spread of misinformation about the lockdown and the curfew in addition to the pervasiveness of fake health information circulating on social media. The public Facebook group El khabar Moukades was also created to counter infodemic. 


\section{Teams, procedures and strategies}

One main thing we noticed about the platform's teams, is the lack of training. While some of the fact-checkers we contacted had fact-checking training, others did not have any. One of the journalists indicated that "it is not necessary to have a training dedicated to fact-checking." This journalist and many others rely on their basic journalism education and the cross-checking techniques they learned in media and journalism training centers and schools. Besides, a few of these fact checkers are not journalists and have not had any training, which is the case of Anti Fake News Tunisie platform. These latter were founded based on personal interest in fake news and fact-checking by the founders.

Training and workshops are critical to ensure quality of journalism and update the journalists' skills. In Tunisia, many national and international media institutions contributed to training Tunisian journalists in fact-checking. Since 2017, the European Union program, Media UP, has been conducting several training sessions through the Tunisian training center, CAPJC. ${ }^{17}$ Other international NGOs such as the American organization Inter News and the German organization Deutsche Welle Akademie conducted training workshops for the Tunisian journalists. Besides, Médias Et Démocratie, a French NGO promoting political transition in Africa, collaborated with the Institute of Press and Information Sciences (IPSI) to organize workshops about risks related to Fake news and how to overcome it. These workshops were the first opportunity for journalism students from Tunisia and Mauritania to specifically learn about Fake News and tools to counteract it. These trainings - designed by Tunisian media schools and centers and supported by international efforts - are updating the skills of current journalists and preparing future generations of journalists with skills necessaries to detect and manage misinformation. The educational board of IPSI designed a course to include fact-checking in its educational curriculum starting from the 2019-2020 academic year. Furthermore, in early 2020, IPSI added a fact-checking club where students learn from the experience of guest specialists and trainers and practice hands-on fact-checking.

Given the lack of any science journalist or science communication specialist in any of the platforms, it is essential to train and prepare journalists who are specialized in these areas. In the context of the COVID-19 outbreak and scientific information in general, the lack of trainings can be quite problematic, especially that none of these fact-checkers is a science journalist or specialized in science or health communication. Science journalists play the role of intermediary between the scientists and the public. They should not only know how to package the information to be comprehensible by a wide audience but also ensure that the information is accurately transferred to the public [Schäfer, 2011]. Furthermore, science is often a continuous work especially when it comes to understanding and managing phenomena such as outbreaks. Consequently, scientific journalism must know how to relay to the public information that is not always clear-cut or complete [Schäfer, 2011]. Hence, expertise and specialization are critical in science communication and journalism, especially in the context of a pandemic. Schäfer [2011] distinguishes between professional fact-checkers and journalists whose fact-checking is only part of their journalism work and training while the former

\footnotetext{
${ }^{17}$ For example, between September 2017 and June 2019 Media UP has organized 4 training sessions in Fact-checking to which 37 journalists have participated.
} 
acquires skills specific to detecting and dismantling misinformation and misleading news. COVID-19 has prompted interest in fact-checking trainings. For example, during August 2020 the NGOs IWatch and Friedrich Naumann have organized separately two different trainings in Fact-checking for journalists in Tunisia.

We must note that none of the resources available in the county rely on automated strategies. All of them rely on human fact-checking techniques such as cross-checking, contacting the original source or the persons quoted in the news, or using search engines and other available online sources such as Google Image, Youtube Data Viewer, and TinEye. Thus, we can conclude that the trainings should focus mainly on manual fact-checking process and bring attention to the importance of acquiring skills in the automated one. The purpose is not to replace one with the other but to combine both processes as suggested by the literature [Goasdoué et al., 2013; Vlachos and Riedel, 2014].

While most of the platforms work solely for their own programs or web platforms, many provide their audiences with fact checked news that they collect from other platforms. The Facebook group and page El Khabar Moukades and El Marsad Ettounsni Li Moukafahat El Akhbar Ezzaifa include professional fact-checking journalists but most of their content is gathered from other platforms. These journalists have adopted a collaborative approach. Indeed, this approach is one of the main characteristics of social media as it is designed for interaction and collaborative work. In the context of emergency events generated by the pandemic, journalists had to improvise ways to counter the sea of COVID-19-related fake news. The solution was these "collected" fact-checked news platforms.

In addition to collecting fact checked news from each other, these platforms engage in deliberate collaborations to exchange tools and resources such as fact-checking guidelines, instructions, software, and training opportunities. For example, in June 2020, the main public TV channel, Al Watanya TV 1, was attracted by Falso's quick success and popularity and solicited their group's help to present a fact-checking segment in the TV weekly show, Monitoring. The show is dedicated to discussing issues related to the media such as journalism practices, regulations, and misinformation. This, in fact, means that public media and professional journalists are relying on the fact-checking efforts of a team of activists that launched an initiative on Facebook. Their abounding activities at the beginning of the pandemic have facilitated their recognition from other well-established media. In May 2018, municipal elections were also the occasion for collaboration between the NGO information website Nawaat.org and the French newspaper Libération, both describe themselves as left leaning media. In fact, the name of the project, Check News Tunisie, was proposed by Liberation. This latter stated that the goal was to test if fact-checking can succeed in Arab countries. In collaboration with a Libération correspondent in Tunisia, Nawaat checked many news related to the Tunisian municipal elections and ended the experience by the end of the elections. One year later, Nawaat built on this short experience to launch its own fact-checking platform, which demonstrates once more that collaborations on the international level are an important facilitator of Tunisian fact-checking platforms.

Several platforms solicit their audience participation in their fact-checking process. Icheck, ask their users to share news or questions that they think should be checked by the platform. Some platforms such as Tunisia Check News, Falso, or ICheck process 


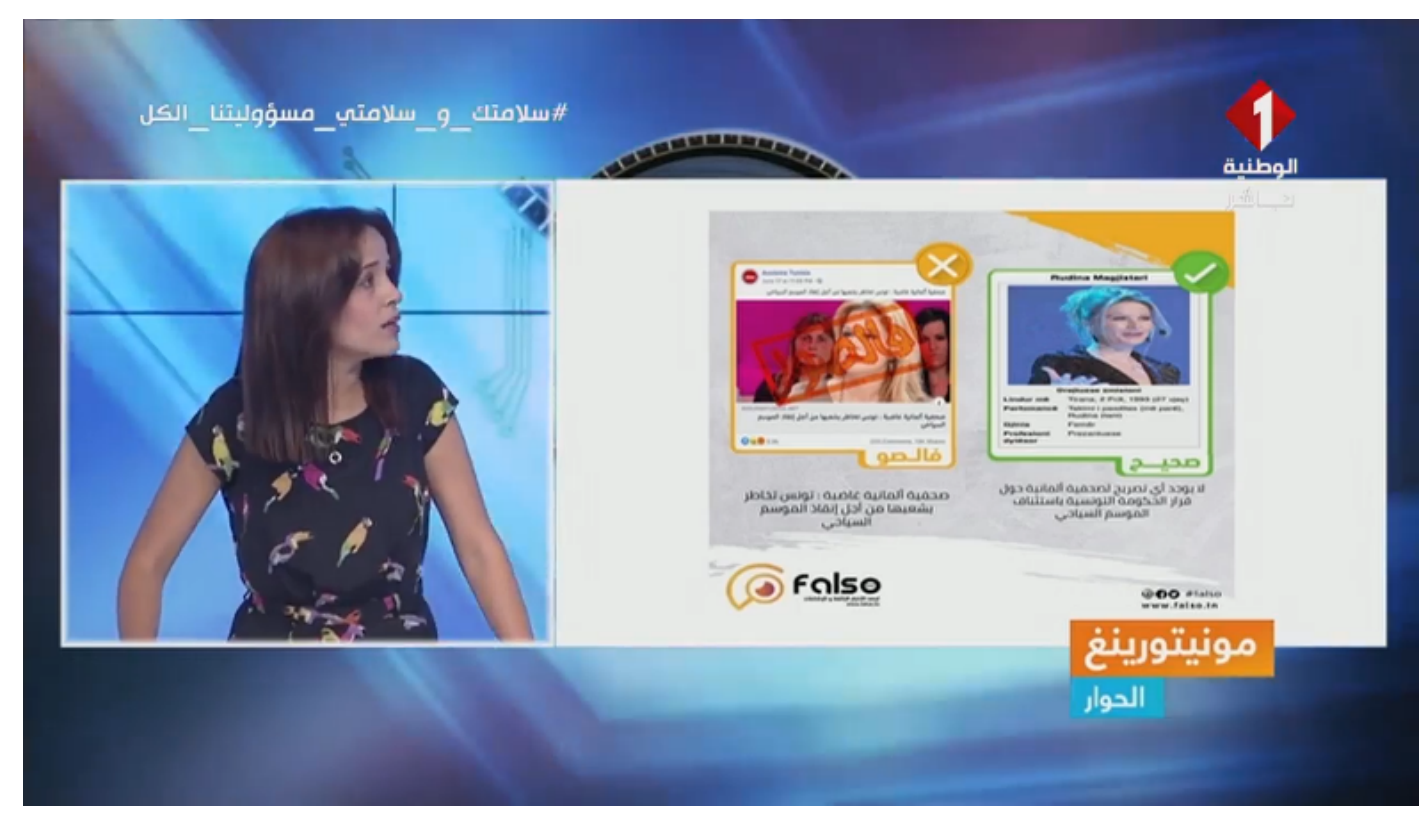

Figure 7. A screenshot from the TV program "Monitoring," in which they invite Falso to discuss news including COVID-19.

the news submitted by their audience and categorize them as true or false. Through this participatory approach they encourage the commitment of users in News accuracy.

Some of these platforms, for example Icheck and Falso, also have sections on their websites in which they classify sources based on their level of misinformation. Icheck, however, claims that it does not check politicized news given that they belong to an apolitical organization. Falso and Icheck, which are the product of civil society initiatives, offer their work to the public and journalists alike without monetary gain or copyright conditions. Nevertheless, the platforms are often the subject of harsh critique from other outlets, especially Falso. Falso is widely criticized for the lack of its founders' professional journalism background even though two of its team members are professional journalists. Many of the other platform founders view fact-checking as a journalism practice and do not approve of someone who is not a journalist engaging in this type of work. On the other hand, civil society activists consider themselves allowed to act as citizen journalists and to contribute together with professionals in ensuring news accuracy. This is also a question of coexistence and legitimacy between traditional media and alternative media. Falso is also criticized for the number of information they check on a daily basis which reaches the 100s on most days while other platforms such as Nawaat, Kashf Media, and BN Check, are very selective about the information they verify. These platforms believe that the large number of information checked by Falso further echoes the misinformation and the pages invested in spreading them. Like Schäfer [2011], Hassan et al. [2015] consider fact-checking "difficult and time-consuming" process for journalists (p. 2).

ICheck is criticized for being the product of IWatch, an NGO that is often attacked for investigating and highlighting sensitive topics (e.g. corruption, nepotism, money laundering) under the pretense that it is funded by foreign services to disturb the Tunisian peaceful transition. In general, the work of alternative media 
and civil society organizations is often criticized in Tunisia by traditional media establishments. However, many fact-checking projects around the world have been launched by civil society organizations such as the NGO Full Fact ${ }^{18}$ in the United Kingdom or Africa Check ${ }^{19}$ in South Africa, which was established by an organization with the same name. It is important to mention that while research on fact-checking trends in 2019 revealed that civil society-based fact-checking platforms are more common in places lacking freedom of expression and freedom of the press [Hawks and Uzunoğlu, 2019], the examples of South Africa, the U.K., or the Tunisia experiences are operating in a free press and political climate. Civil society organizations are expected to participate in holding politicians and public figures accountable. Thus, it is only normal that they engage in fact-checking practices [Hawks and Uzunoğlu, 2019; Orso et al., 2020].

\section{Conclusion}

In this paper, we mapped the fact-checking resources in the newly found Tunisian freedom of speech and press while focusing on how COVID-19 impacted the fact-checking landscape. We found that although Tunisia has been undeniably catching up to the fact-checking trend since 2014, COVID-19 created a clear change in the field given the sharp increase in the number of platforms and resources since February 2020. COVID-19 created a context in which fact-checking platforms have emerged and flourished notably. Most of them were a product of associative and civil society initiatives. However, NGOs are criticized from traditional media practitioners due to a general sense of mistrust in the role of NGOs in the post-revolution Tunisia and the lack of professional journalists in these platforms. These discrepancies highlight a debate in the Tunisian post-revolution press field about the legitimacy of those who do journalism work without a journalism training or education, including those who perform citizen journalism. Since 2011 many professional norms, practices and issues are still evaluating themselves and their missions. Fact-checking is emerging in a context in which the Tunisian press field is redesigned and redefined. COVID-19 has only heightened the debate about several journalism-related issues.

In terms of the resources, we noticed a lack of fact-checking platforms in the broadcast media, especially in TV channels, except for a few segments within several programs and shows. Most of the available platforms are electronic, websites and Facebook pages. However, a few of these platforms are evolving into well-established fact-checking institutions, such as Falso, which started as a Facebook page and is currently evolving into a website as it continues to steadily garner national attention. Besides, fact-checking is completely absent in written Newspapers. However, in the U.S. for instance, the famous fact-checking initiatives have been launched by newspapers such as Politifact.com, a product of Tampa Bay Times and Fact Checker, a product of The Washington Post. Both mainly provide fact-checking online. The situation is different in Tunisia where print media is confronting various structural problems in their digital transition. The exclusive use of human fact-checking is also symptomatic of low involvement of ICT in the innovation of the Tunisian media in general.

\footnotetext{
${ }^{18} \mathrm{http}: / /$ www.fullfact.org (accessed on 12 June 2020).

${ }^{19}$ http:/ / www.africacheck.org (accessed on 12 June 2020).
} 
Nevertheless, we believe that the Tunisia media ecology exhibits signs of media fragility that spills to its fact-checking scene. First, Tunisian media are affected by the national economic crisis that is only worsening with the COVID-19 outbreak, which is why many of those working in the platforms are not professional fact-checkers. The complete absence of fact-checkers specialized in science communication and science journalism may also pose a problem and a threat to the ability to evaluate information and relay them to the public. Furthermore, the fact that many institutions have relied on external funds to establish a fact-checking platform raises the question about the independence of these platforms and the level of influence of the funders on the institution's work.

On another note, the lack of strategic editorial decisions to include fact-checking in the line of work, adds another dimension to the fragile media scene. Although it is still early to postulate the survival of the initiatives motivated by COVID-19, there is always the risk of these platforms being only a fad engendered by the pandemic and the risk that they would disappear without a sustainable working strategy and financial support. Furthermore, many of our interviewees lack an understanding of the difference between journalists' cross-checking practices and fact checking as a specialty requiring different expertise. Without a doubt, the civil society, media, and citizens seem aware of the threat of misinformation. They also demonstrate clear signs of diversity in terms of the type and practices of the fact-checking initiatives. However, none of this is a guarantee for continuity and sustainability. For these reasons, further research is necessary to follow up with the resources and examine their long-term trajectories.

Fact-checking is emerging in Tunisia in which the media seem committed to a challenging transition process. They are operating in the environment of democratic transition characterized by political instability and intense public mistrust in both the media and politics. For example, the press council created to ensure ethical media practices remains inactive, demonstrating and further contributing to the fragile media and politic scene.

That being said, it is clear that COVID-19 shook the media landscape not only in Tunisia but all over the world. It has prompted a sharp increase in Tunisian fact-checking platforms and prompted journalists and media figures to rethink their practices, their audiences, and their establishments. Thus, future research should investigate the reception of these fact-checking by audiences and news consumers. Future research should also examine the trajectory of these platforms and their work practices. We believe that building on the current research will provide a basis to have a more holistic understanding of the Tunisian and North African media ecology during and in the aftermath of a pandemic. 


\begin{tabular}{|c|c|c|c|c|}
\hline Name & Institution & $\begin{array}{l}\text { Type of the } \\
\text { Media }\end{array}$ & $\begin{array}{l}\text { Inception } \\
\text { Date }\end{array}$ & Motivation \\
\hline Berrassmi & $\begin{array}{l}\text { Les Cahiers de la } \\
\text { Liberté }\end{array}$ & Website & 2014 & $\begin{array}{l}\text { To verify politicians' claims } \\
\text { during the Presidential elec- } \\
\text { tions campaign. }\end{array}$ \\
\hline Esshih Mel Ghalet & Watanya TV 1 & Public TV & Oct 2017 & $\begin{array}{l}\text { Interest in fact-checking news } \\
\text { by the journalist (section in a } \\
\text { daily news talk show) }\end{array}$ \\
\hline $\begin{array}{l}\text { On a vérifié pour } \\
\text { vous }\end{array}$ & RTCI & Public Radio & 2018 & $\begin{array}{l}\text { Journalist's initiative inspired } \\
\text { by a Training in explanatory } \\
\text { journalism; self-taught in fact- } \\
\text { checking }\end{array}$ \\
\hline Le vrai du Faux & Express FM & Pirvate Radio & May 2018 & Journalist's initiative \\
\hline Esshih Mel Ghalet & Diwan FM & Private Radio & August 2018 & $\begin{array}{l}\text { Journalist's initiative after a } \\
\text { training in fact-checking }\end{array}$ \\
\hline BN Check & Business News & $\begin{array}{l}\text { Online News } \\
\text { Magazine }\end{array}$ & Aug 19, 2019 & $\begin{array}{l}\text { Motivated by the need of } \\
\text { fact-checking information and } \\
\text { news }\end{array}$ \\
\hline Tunisia Check News & $\begin{array}{l}\text { A fact-checking col- } \\
\text { laboration between } \\
\text { TAP; Watanya 1; } \\
\text { Tunisian Public } \\
\text { Radio }\end{array}$ & A website & $\begin{array}{l}\text { September } \\
2019\end{array}$ & $\begin{array}{l}\text { Motivated by the availabil- } \\
\text { ity of Funds from the PNUD, } \\
\text { journalists formed to ensure } \\
\text { fact-cheking. The project } \\
\text { stopped and then resumed } \\
\text { due to the pandemic. }\end{array}$ \\
\hline Haw Esshih & Shems FM & Pivate Radio & March 2020 & $\begin{array}{l}\text { To verify information about } \\
\text { COVID-19 }\end{array}$ \\
\hline Kashf khabar & Kashf Media & $\begin{array}{lr}\text { NGO On- } \\
\text { line News } \\
\text { Magazine }\end{array}$ & March 2020 & $\begin{array}{l}\text { Engaging in innovative } \\
\text { formats of media content: } \\
\text { fact-checking, data journal- } \\
\text { ism... }\end{array}$ \\
\hline Nawaat Fact Check & Nawaat & $\begin{array}{lr}\text { NGO On- } \\
\text { line News } \\
\text { Magazine }\end{array}$ & March 19, 2020 & $\begin{array}{l}\text { Motivated by misformation } \\
\text { related the COVID-19 }\end{array}$ \\
\hline $\begin{array}{l}\text { El Marsad Ettoun- } \\
\text { sni Li Moukafahat } \\
\text { El Akhbar Ezzaifa }\end{array}$ & $\begin{array}{l}\text { Independent initiat- } \\
\text { ive }\end{array}$ & $\begin{array}{l}\text { Private Face- } \\
\text { book Group }\end{array}$ & Mar 21, 2020 & Interest in fact-checking \\
\hline $\begin{array}{ll}\text { El } & \text { Khabar } \\
\text { Moukades } & \end{array}$ & $\begin{array}{l}\text { Independent initiat- } \\
\text { ive }\end{array}$ & $\begin{array}{l}\text { Facebook } \\
\text { Group }\end{array}$ & March 22, 2020 & $\begin{array}{l}\text { Motivated by COVID- } 19 \text { mis- } \\
\text { information and intending to } \\
\text { keep the initiative until the } \\
\text { pandemic is over }\end{array}$ \\
\hline Falso & $\begin{array}{l}\text { Independent initiat- } \\
\text { ive }\end{array}$ & $\begin{array}{l}\text { Facebook Page } \\
\text { and Website }\end{array}$ & April 10, 2020 & $\begin{array}{l}\text { Interest in fact-checking and } \\
\text { motivation by misinformation } \\
\text { related to COVID-19 }\end{array}$ \\
\hline iCheck & IWatch & $\begin{array}{l}\text { Facebook Page } \\
\text { and Website }\end{array}$ & April 19, 2020 & $\begin{array}{l}\text { Engaging provide a fact- } \\
\text { cheking ressource and } \\
\text { motivated by COVID-19 } \\
\text { misinformation }\end{array}$ \\
\hline $\begin{array}{l}\text { Anti Fake News } \\
\text { Tunisie }\end{array}$ & $\begin{array}{l}\text { Independent initiat- } \\
\text { ive }\end{array}$ & Facebook Page & $\begin{array}{l}\text { February } 11, \\
2020\end{array}$ & Self-interested \\
\hline
\end{tabular}




\begin{tabular}{|c|c|c|}
\hline Name & Teams & Strategies \& Procedures \\
\hline Berrassmi & Data not available & Data not available \\
\hline $\begin{array}{l}\text { Esshih Mel Ghalet } \\
\text { (Watanya 1) }\end{array}$ & $\begin{array}{l}\text { A Journalist interested in fact- } \\
\text { checking }\end{array}$ & $\begin{array}{l}\text { Human: Chooses a news item or an inform- } \\
\text { ation to verify by contacting sources. }\end{array}$ \\
\hline $\begin{array}{l}\text { On a vérifié pour } \\
\text { vous (RTCI) }\end{array}$ & $\begin{array}{l}\text { A journalist working for the } \\
\text { daily Newspaper La Presse }\end{array}$ & $\begin{array}{l}\text { Human: call of original sources }+ \text { use of } \\
\text { technical tools like Google Image Reverse or } \\
\text { Youtube Data viewer. }\end{array}$ \\
\hline $\begin{array}{l}\text { Le vrai du Faux (Ex- } \\
\text { press FM) }\end{array}$ & $\begin{array}{l}\text { A Journalist (thinks that there } \\
\text { is no need of specific training } \\
\text { in fact-checking) }\end{array}$ & $\begin{array}{l}\text { Human: relies on contacting sources with } \\
\text { rare use of other electronic tools in fact- } \\
\text { checking. }\end{array}$ \\
\hline $\begin{array}{l}\text { Esshih Mel Ghalet } \\
\text { (Diwan FM) }\end{array}$ & $\begin{array}{l}\text { A Journalist Trained in fact- } \\
\text { checking }\end{array}$ & Human: reilies on contacting sources. \\
\hline $\begin{array}{l}\text { BN Check (Business } \\
\text { News) }\end{array}$ & 8 journalits: the whole team & Human: they verify by contacting sources \\
\hline $\begin{array}{l}\text { Tunisia check news } \\
\text { (TAP; Watanya 1; } \\
\text { Tunisian Radio) }\end{array}$ & $\begin{array}{l}\text { Journalists trained in fact- } \\
\text { checking from different me- } \\
\text { dia:the national press agency } \\
\text { TAP; Public TV Watanya 1; } \\
\text { Tunisian Public Radio. }\end{array}$ & $\begin{array}{l}\text { Human: work on verifying news and in- } \\
\text { formation with casual use of electronic } \\
\text { tools. }\end{array}$ \\
\hline $\begin{array}{l}\text { Haw Esshih (Shems } \\
\text { FM) }\end{array}$ & 2 journalists & Human: they verify by contacting sources. \\
\hline $\begin{array}{l}\text { Kashf khabar (Kashf } \\
\text { Media) }\end{array}$ & Journalists & $\begin{array}{l}\text { Human: they verify by contacting sources } \\
\text { or using electronic tools. }\end{array}$ \\
\hline $\begin{array}{l}\text { Nawaat Fact Check } \\
\text { (Nawaat) }\end{array}$ & $\begin{array}{l}6 \text { Journalists: the whole web- } \\
\text { site team participate }\end{array}$ & $\begin{array}{l}\text { Human: study the stucture and the sruces } \\
\text { of the news to be verified and they contact } \\
\text { sources or check online ressources. }\end{array}$ \\
\hline $\begin{array}{l}\text { El Marsad Ettoun- } \\
\text { sni Li Moukafahat } \\
\text { El Akhbar Ezzaifa }\end{array}$ & $\begin{array}{l}\text { Music Professor interested } \\
\text { and trained in journalism }+\mathrm{A} \\
\text { Journalist }\end{array}$ & Republish verified Information \\
\hline $\begin{array}{ll}\text { El } & \text { Khabar } \\
\text { Moukades } & \end{array}$ & Academia and Journalists & $\begin{array}{l}\text { Human: Group Members republish verified } \\
\text { News by other platforms and share useful } \\
\text { information and tools related to factcheck- } \\
\text { ing. }\end{array}$ \\
\hline Falso & $\begin{array}{l}7 \text { activists including journal- } \\
\text { ists }\end{array}$ & $\begin{array}{l}\text { Human: they verify by contacting sources } \\
\text { and using electronic tools. Ask users to post } \\
\text { news and information to bec fact-checked. }\end{array}$ \\
\hline icheck (IWatch) & $\begin{array}{l}3 \text { journalists trained in fact- } \\
\text { checking }\end{array}$ & $\begin{array}{l}\text { Human: they verify by contacting sources } \\
\text { and using electronic tools. Ask users to post } \\
\text { news and information to bec fact-checked. }\end{array}$ \\
\hline $\begin{array}{l}\text { Anti Fake News } \\
\text { Tunisie }\end{array}$ & Computer Engineer & $\begin{array}{l}\text { Republish news and information verified by } \\
\text { other platforms }\end{array}$ \\
\hline
\end{tabular}


Appendix C. Index 3

\begin{tabular}{|l|l|l|}
\hline Name & Link (if available) & Status \\
\hline Berrassmi & http://birrasmi.tn/ & Active (during elections) \\
\hline Esshih Mel Ghalet (Watanya 1) & Not available & Removed on May 2018 \\
\hline On a vérifié pour vous (RTCI) & Not available & Removed on July 2019 \\
\hline Le vrai du Faux (Express FM) & https://bit.ly/3hAcxqB & Active \\
\hline $\begin{array}{l}\text { Esshih Mel Ghalet (Diwan } \\
\text { FM) }\end{array}$ & https://bit.ly/2EKoifi & Active \\
\hline BN Check (Business News) & https://www.businessnews.com.tn/bncheck & Active \\
\hline $\begin{array}{l}\text { Tunisia Check News (TAP; } \\
\text { Watanya 1; Tunisian Radio) }\end{array}$ & http://www.tunisiachecknews.com/ & Active \\
\hline Haw Esshih (Shems FM) & Not available & Removed on April 2020 \\
\hline Kashf khabar (Kashf Media) & https://bit.ly/34L5CqK & Active \\
\hline Nawaat Fact Check (Nawaat) & https://nawaat.org/tag/nawaat-fact-check/ & Active \\
\hline $\begin{array}{l}\text { El Marsad Ettounsni Li } \\
\text { Moukafahat El Akhbar } \\
\text { Ezzaifa }\end{array}$ & Not available (private facebook group) & Inactive \\
\hline El Khabar Moukades & https://bit.ly/3gO9V7m & \\
\hline Falso & https://falso.tn/ & Active \\
\hline icheck (IWatch) & https://icheck.tn/ & Active \\
\hline Anti Fake News Tunisie & https://bit.ly/2GfUMil & Active \\
\hline
\end{tabular}

References 
Chadwick, A. (2017). The hybrid media system: politics and power. Oxford, U.K.: Oxford University Press. https://doi.org/10.1093/acprof : oso/9780199759477.001.0001.

Chouikha, L. (2015). Des séquelles de l'étatisation aux aléas de la transition. La difficile transformation des médias. Des années de l'indépendance à la veille des élections de 2014. [Sequals of statehood in the risks of transition. The difficulties of media transformation. From the years of independence to the 2014 elections]. Tunis, Tunisia: Finzi.

Cinelli, M., Quattrochiocchi, W., Galeazzi, A., Valensise, C. M., Brugnoli, E., Schmidt, A. L., Zola, P., Zollo, F. and Scala, A. (2020). 'The COVID-19 social media infodemic'. arXiv: 2003.05004. (Visited on 25th May 2020).

Figueira, Á. and Oliveira, L. (2017). 'The current state of fake news: challenges and opportunities'. Procedia Computer Science 121, pp. 817-825.

https://doi .org/10.1016/j . procs . 2017.11.106. (Visited on 18th June 2020).

Goasdoué, F., Karanasos, K., Katsis, Y., Leblay, J., Manolescu, I. and Stamatis, Z. (2013). 'Fact checking and analyzing the web'. In: SIGMOD - ACM International Conference on Management of Data (New York, NY, U.S.A. June 2013). URL: https://hal.inria.fr/hal-00814285/document (visited on 13th June 2020).

Graves, L. (2017). 'Anatomy of a fact check: objective practice and the contested epistemology of fact checking'. Communication, Culture \& Critique 10 (3), pp. 518-537. https://doi.org/10.1111/cccr.12163.

Hassan, N., Adair, B., Hamilton, J. T., Li, C., Tremayne, M., Yang, J. and Yu, C. (2015). 'The quest to automate fact-checking'. In: Proceedings of the 2015 computation and journalism symposium. URL: http://ranger .uta.edu/ ${ }^{\sim} \mathrm{cli} /$ pubs /2015/claimbuster-cj15-hassan.pdf (visited on 24th June 2020).

Hawks, B. and Uzunoğlu, S. (2019). Polarization, populism and the new politics: media and communication in a changing world. Newcastle-Upon-Tyne, U.K.: Cambridge Scholars Publishing.

Krause, N. M., Freiling, I., Beets, B. and Brossard, D. (2020). 'Fact-checking as risk communication: the multi-layered risk of misinformation in times of COVID-19'. Journal of Risk Research, pp. 1-8. https://doi.org/10.1080/13669877.2020.1756385.

Lee, A. R., Son, S.-M. and Kim, K. K. (2016). 'Information and communication technology overload and social networking service fatigue: a stress perspective'. Computers in Human Behavior 55, pp. 51-61. https://doi.org/10.1016/j.chb.2015.08.011.

Nguyen, A. T., Kharosekar, A., Krishnan, S., Krishnan, S., Tate, E., Wallace, B. C. and Lease, M. (2018). 'Believe it or not: designing a human-AI partnership for mixed-initiative fact-checking'. In: The 31st Annual ACM Symposium on User Interface Software and Technology - UIST '18. ACM Press. https://doi.org/10.1145/3242587.3242666.

Orso, D., Federici, N., Copetti, R., Vetrugno, L. and Bove, T. (2020). 'Infodemic and the spread of fake news in the COVID-19-era'. European Journal of Emergency Medicine 27 (5), pp. 327-328. https://doi.org/10.1097/mej.0000000000000713.

Pulido, C. M., Villarejo-Carballido, B., Redondo-Sama, G. and Gómez, A. (2020). 'COVID-19 infodemic: more retweets for science-based information on coronavirus than for false information'. International Sociology 35 (4), pp. 377-392. https://doi .org/10.1177/0268580920914755. 
Schäfer, M. (2011). 'Science journalism and fact checking'. JCOM 10 (04), C02. https://doi.org/10.22323/2.10040302. (Visited on 22nd June 2020).

Vlachos, A. and Riedel, S. (2014). 'Fact-checking: task definition and dataset construction'. In: Proceedings of the ACL 2014 Workshop on Language Technology and Computational Social Science (Baltimore, MD, U.S.A. 26th June 2014). Association for Computational Linguistics.

URL: https://www.aclweb.org/anthology/W14-2508.pdf (visited on 22nd June 2020).

Waisbord, S. (2018). 'Truth is what happens to news: on journalism, fake news and post-truth'. Journalism Studies 19 (13), pp. 1866-1878. https://doi.org/10.1080/1461670x.2018.1492881.

Zhou, X. and Zafarani, R. (2020). 'A survey of fake news: fundamental theories, detection methods and opportunities'. ACM Computing Surveys 53 (5), pp. 1-40. https://doi.org/10.1145/3395046. arXiv: 1812.00315. (Visited on 29th May 2020).

Authors

Fredj Zamit is Ph.D. in information and communication Science and assistant professor in the Institute of Press and information Science (IPSI) in Tunisia. E-mail: fredj.zamit@yahoo.de.

Arwa Kooli is Ph.D. in information and communication Science and journalist in Dar Assabah. She is also trainer in Data journalism. E-mail: arwa.kooli@gmail.com.

Ikram Toumi is Ph.D. in communication Studies and associate professor in School of Communication Studies in Kent Universtity, U.S.A. E-mail: itoumi@kent.edu.

\section{How to cite}

Zamit, F., Kooli, A. and Toumi, I. (2020). 'An examination of Tunisian fact-checking resources in the context of COVID-19'. JCOM 19 (07), A04.

https://doi.org/10.22323/2.19070204.

(C) The Author(s). This article is licensed under the terms of the Creative Commons Attribution - NonCommercial - NoDerivativeWorks 4.0 License.

ISSN 1824-2049. Published by SISSA Medialab. jcom.sissa.it 